\title{
Struktur komunitas mangrove di perairan pantai Desa Sehati Kabupaten Maluku Tengah
}

\author{
Mangrove community structure in the coastal waters of Sehati Village, \\ Central Maluku Regency
}

\author{
Umar Namakule*, Karel Markus Melsasail \\ Program Studi Pendidikan Biologi, Fakultas Pendidikan Matematika dan Ilmu Pengatahuan Alam, \\ STKIP Gotong Royong Masohi, Jalan Trans Seram Belakang Negeri Haruru Masohi, Indonesia -97514
}

*Email: namakuleumar@gmail.com

Diterima 11 November 2020 Disetujui 3 Juli 2021

\section{INTISARI}

Sehati merupakan salah satu desa yang terletak di Kabupaten Maluku Tengah yang memiliki kawasan mangrove dengan luasan 66.5 ha dimanfaatkan sebagai salah satu objek wisata lokal. Sarana pendukung pariwisata dibangun untuk meningkatkan estetika kawasan akan tetapi berimplikasi pada alih guna lahan mangrove. Tutupan mangrove menjadi berkurang karena adanya penebangan oleh masyarakat setempat dan intensitas sampah plastik dalam kawasan mengalami peningkatan seiring dengan rendahnya kesadaran pengunjung. Aktivitas pariwisata tersebut memberikan tekanan yang cukup berarti bagi ekosistem mangrove di Desa Sehati. Tujuan dari penelitian ini untuk menganalisis struktur komunitas serta kondisi lingkungan substrat dan perairan pada kawasan hutan mangrove di Desa Sehati, Kabupaten Maluku Tengah. Pengumpulan data dilakukan dengan metode transek liniear kuadrat. Transek yang digunakan sebanyak 5 buah dengan kuadrat berukuran 3x3 meter sebanyak 10 buah, serta didukung dengan pengukuran berbagai parameter fisika kima perairan. Jenis mangrove yang ditemukan diperairan pantai Desa Sehati sebanyak 5 jenis. Nilai indeks keanekaragaman tergolong sedang $(0,965)$, indeks dominansi tergolong tinggi $(0,893)$, dan indeks kemerataan tergolong sedang $(0,348)$. Rhizphora apiculata memiliki nilai kerapatan (12,78 ind/m2), kelimpahan (23 ind/m2), frekuensi kehadiran $(0,96 \%)$, dan indeks nilai penting $(103,56)$ yang paling tinggi. Kondisi faktor fisika kimia perairan masih berada dalam keadaan yang baik bagi pertumbuhan mangrove.

Kata kunci: faktor fisika kimia, mangrove, metode transek, struktur komunitas

\begin{abstract}
Sehati is one of the villages located in Central Maluku Regency which has a mangrove area with an area of 66,5 ha which is used as a local tourist attraction. Tourism support facilities are built to improve the aesthetics of the area but have implications for the conversion of mangrove land. Mangrove cover is reduced due to logging by local communities and the intensity of plastic waste in the area has increased along with the low awareness of visitors. These tourism activities put significant pressure on the mangrove ecosystem in Sehati village. The purpose of this study was to analyze the community structure and environmental conditions of the substrate and waters in the mangrove forest area in Sehati village, Central Maluku Regency. Data collection was performed using the linear squared transect method. The transects used are 5 pieces with squared measuring $3 \times 3$ meter as many as 10 pieces and are supported of various parameters
\end{abstract}


oh water physics and chemistry. There are 5 species of mangroves found in the coastal village waters. The diversity index value is low $(0,348)$, the dominance index is high $(0,893)$, and the evenness index is low $(0,348)$. Rhizophora apiculata has the highest value of density $(12,78 \mathrm{ind} / \mathrm{m} 2)$, abundance $(23 \mathrm{ind} / \mathrm{m} 2)$, attendance frequency $(0,96 \%)$, and index of importance $(103,56)$. Physical and chemical conditions of waters are still in a good condition for the growth of magroves.

\section{Keywords: community structure, mangrove, physic and chemist factor, transect method}

\section{PENDAHULUAN}

Mangrove merupakan komunitas tumbuhan pantai yang mampu beradaptasi pada lingkungan ekstrim. Komunitas mangrove tumbuh pada habitat dengan substrat pasir, lumpur dan berbatu pada zona intertidal (Kustianti, 2011; Indawan et al., 2012), substrat yang rendah oksigen, serta perairan yang memiliki kadar garam. Sistem perakaran yang unik dengan adanya struktur lenticel dan pneumatophore, memberikan kemampuan adaptasi mangrove terhadap rendahnya oksigen untuk respirasi dalam substrat, Selain itu mangrove dapat meregulasi kadar garam pada perairan secara fisiologis untuk memperoleh air yang digunakan dalam metabolisme tubuh. Setiap jenis mangrove memiliki kemampuan adaptasi yang berbeda, sehingga variasi salinitas akan memberikan zonasi pada hutan mangrove serta mempengaruhi keanekaragaman jenis mangrove (Noor et al., 2012). Jenis Sonneratia alba memiliki kemampuan adaptasi yang sangat baik pada habitat salinitas tinggi yang umumnya ditemukan pada zona depan (Ball and Pidsley, 1995). Sementara itu, pada daerah dengan salinitas rendah jenis Nypa fruticans, Lumnitzera littorea, dan Xylocarpus granatum cenderung lebih mudah diperoleh (Noor et al., 2012).

Sebagai komunitas tumbuhan di kawasan intertidal, mangrove berkontribusi penting secara ekologi, fisik dan kimia, serta sosial ekonomi masyarakat sekitar. Secara ekologi, mangrove berfungsi penting dalam siklus hidup berbagai jenis ikan, kepiting, udang, gastropoda, dan moluska karena lingkungan mangrove dijadikan sebagai tempat pemijahan (spawning ground), tempat asuhan (nursery ground), serta penyedia makanan (feeding ground) berupa bahan-bahan organik yang masuk ke dalam rantai makanan. (Prasetiyo et al., 2016). Selain itu, produksi serasah mangrove berperan penting dalam meningkatkan kesuburan perairan. Di Indonesia, produksi serasah mangrove berkisar antara 7-8 ton/ha per tahun (Noor et al., 2012). Dengan demikian hutan mangrove dianggap yang paling produktif diantara ekosistem pesisir Sementara itu, fungsi fisik mangrove untuk melindungi pantai dari gelombang (Rahmawati, 2006). Tegakan mangrove dapat juga melindungi pemukiman masyarakat dari angin kencang atau intrusi air laut. Mangrove juga terbukti memainkan peranan penting dalam melindungi pantai dari gempuran badai. Noor et al. (2012) menjelaskan bahwa Dusun Tongke-Tongke dan Pangasa, Sulawesi Selatan memiliki barisan mangrove yang tebal di pantai sehingga terlindung dari gelombang pasang (Tsunami). Sementara itu, beberapa dusun yang berbatasan dengan kedua dusun tersebut tidak memiliki mangrove yang tebal sehingga mengalami kerusakan yang cukup parah. Berbagai produk dari mangrove dapat dihasilkan baik secara langsung maupun tidak langsung diantaranya sumber bahan bakar (kayu), bahan bangunan (papan), biodiesel, obat-obatan, dan bioenergi sebagai fungsi sosial ekonomi masyarakat (Tuhuteru dan Mahfuds, 2012; Kariada dan Andin, 2014). Produk yang memiliki nilai ekonomis tinggi dari ekosistem mangrove adalah perikanan. Banyak ikan yang bernilai ekonomis tinggi seperti kakap (Lates calcacifer), kepiting mangrove (Scylla serrata), serta ikan salmon (Polynemus sheridani) menghabiskan sebagian siklus hidupnya pada ekosistem mangrove (Noor et al., 2012). Oleh karena itu, mangrove perlu dilestarikan untuk mempertahankan fungsi mangrove terhadap komunitas sekitarnya. 
Saat ini, kawasan mangrove Desa Sehati dengan luasan 66.5 ha, dimanfaatkan sebagai salah satu objek wisata lokal. Sarana pendukung pariwisata dibangun untuk meningkatkan estetika kawasan. Pembangunan sarana tersebut berimplikasi pada alih guna lahan mangrove. Penebangan juga sering ditemukan dalam kawasan oleh masyarakat setempat sehingga tutupan mangrove menjadi berkurang. Selain itu, intensitas sampah plastik dalam kawasan mengalami peningkatan seiring dengan rendahnya kesadaran pengunjung. Aktivitas pariwisata tersebut memberikan tekanan yang cukup berarti bagi ekosistem mangrove di perairan pantai Desa Sehati, namun penelitian tentang kondisi terkini hutan mangrove di perairan pantai Desa Sehati belum dilakukan untuk pemantauan kondisi kawasan. Oleh karena

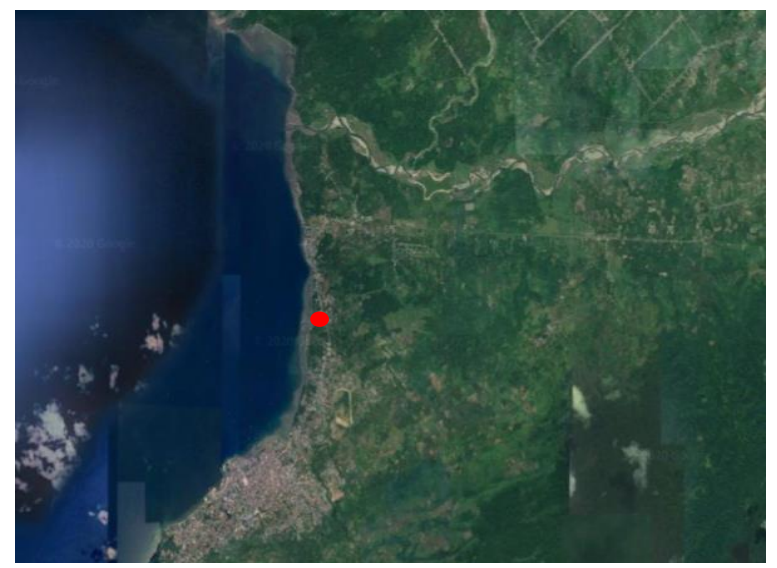

(a) itu, penelitian ini bertujuan untuk menganalisis struktur komunitas serta kondisi lingkungan substrat dan perairan pada kawasan hutan mangrove di perairan pantai Desa Sehati, Kabupaten Maluku Tengah. Penelitian ini diharapkan sebagai data potensi dan kondisi terkini dari hutan mangrove yang dapat digunakan dalam pengelolaan mangrove yang lebih baik dan berkelanjutan di perairan pantai Desa Sehati.

\section{MATERI DAN METODE}

\section{Tempat dan waktu penelitian}

Penelitian ini dilaksanakan di perairan pantai Desa Sehati Kabupaten Maluku Tengah (Gambar 1) pada bulan Juni-Juli 2020.

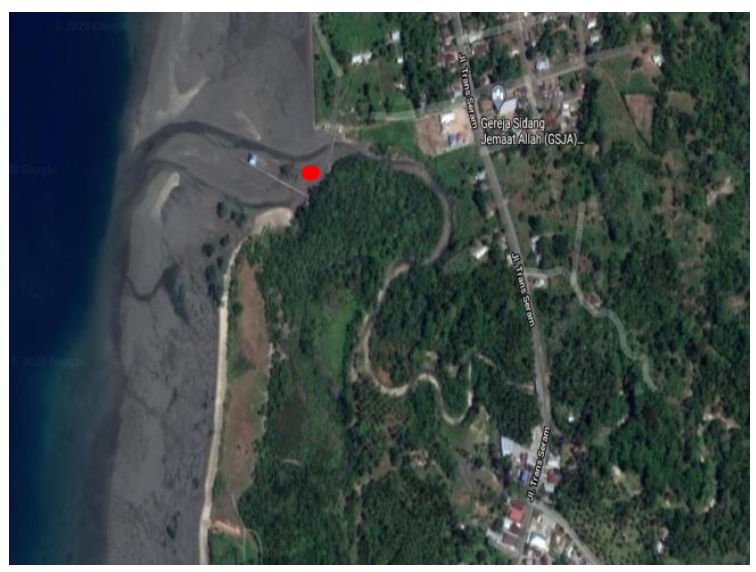

(b)

Gambar 1.Lokasi penelitian (a) Pulau Maluku; dan (b) Pantai Desa Sehati Kabupaten Maluku Tengah

\section{Alat dan bahan}

Alat yang digunakan dalam penelitian ini adalah pipa paralon PVC $1 / 2$ inch untuk membuat kuadrat, tali nilon untuk membuat transek, meteran tancap 100 meter untuk mengukur jarak antartransek dan kuadrat, thermometer untuk mengukur suhu, bola arus untuk mengukur kuat arus, tongkat berskala untuk mengukur kedalaman, refaktometer untuk mengukur salinitas, dan $\mathrm{pH}$ meter untuk mengukur $\mathrm{pH}$, Adapun bahan yang digunakan adalah formaldehida $4 \%$ untuk mengawetkan sampel jenis mangrove.

\section{Analisis struktur komunitas mangrove}

Dibuat 5 buah transek di perairan pantai Desa Sehati sepanjang 100 meter dengan jarak antartransek 50 meter. Pada masing-masing transek diletakan kuadrat dengan ukuran $3 \times 3$ meter (Sasauw et al., 2016). Mangrove yang terdapat di dalam setiap kuadrat dihitung jumlah jenisnya. Data jumlah jenis mangrove digunakan untuk menghitung nilai struktur komunitas (Akbar et al., 2016). Mangrove yang ditemukan diidentifikasi menggunakan acuan menurut Noor et al. (2012). 


\section{Pengukuran Faktor Lingkungan}

Faktor lingkungan yang diukur adalah faktor fisika perairan berupa suhu air laut menggunakan termometer air raksa, kuat arus air laut menggunaan bola arus, dan kedalaman air laut menggunakan tongkat berskala. Adapun faktor kimia perairan yang diukur berupa salinitas air laut menggunakan refaktometer dan $\mathrm{pH}$ air laut menggunakan $\mathrm{pH}$ meter.

\section{Analisis data}

Data struktur komunitas mangrove dihitung dengan menggunakan rumus-rumus sebagai berikut:

1. Indeks keanekaragaman: $H^{\prime}=-\sum P i \ln P i$, dimana $P i=\frac{n i}{N}$

$H^{\prime}$ adalah indeks keanekaragaman, $P i$ adalah probalitas jenis ke-i, $n i$ adalah jumlah individu jenis ke-i, $N$ adalah jumlah total individu, dan $\ln$ adalah logaritma nature (Odum, 1993). Kriteria keanekaragaman jenis sebagai berikut: jika H'>3, maka keanekaragaman jenis tinggi; jika $1<\mathrm{H}^{\prime}<3$, maka keanekaragaman jenis sedang; dan jika $\mathrm{H}^{\prime}<1$, maka keanekaragaman jenis rendah (Odum, 1993).

2. Indeks dominansi: $D=\frac{\sum n i(n i-1)}{N(N-1)}$

$D$ adalah indeks dominansi, $n i$ adalah jumlah individu jenis ke-i, dan $N$ adalah jumlah total individu (Odum, 1993). Kriteria dominansi sebagai berikut: jika $0,5<\mathrm{D}<1$, maka dominansi tinggi (terdapat jenis yang mendominansi); dan jika jika $0<\mathrm{D}<0,5$, maka dominansi rendah (tidak ada jenis yang mendominansi) (Renta et al., 2016).

3. Indeks kemerataan: $E=\frac{H^{\prime}}{\ln S}$

$E$ adalah indeks kemerataan, $H^{\prime}$ adalah indeks keanekaragaman jenis, dan $S$ adalah jumlah total jenis, dan $\ln$ adalah logaritma nature (Odum, 1993). Kriteria kemerataan sebagai berikut: jika E $\geq 0,6$, maka kemerataan jenis tinggi; jika $0,4<E$ $<0,6$, maka kemerataan jenis sedang; dan jika $E$ $<0,4$, maka kemerataan jenis rendah (Renta et al., 2016).

\section{Kerapatan: $K i=\frac{n i}{A}$}

$K i$ adalah kerapatan, $n i$ adalah jumlah individu jenis ke-i, dan $A$ adalah luas area pengambilan sampel (Krebs, 1978; Fachrul, 2008).

5. Kerapatan realtif: $K R=\frac{K i}{\sum K} \times 100 \%$

$K R$ adalah kerapatan relatif, $K i$ adalah kerapatan jenis ke-i, dan $\sum K$ adalah jumlah kerapatan semua jenis (Krebs, 1978; Fachrul, 2008).

6. Kelimpahan: $K L i-\frac{n i}{T}$

$K L i$ adalah kelimpahan, $n i$ adalah jumlah individu jenis ke-i, dan $T$ adalah total transek ditemukannya jenis ke-I (Soegianto, 1994).

7. Kelimpahan realtif: $K L R=\frac{K L i}{\sum K L i} \times 100 \%$

$K L R$ adalah kelimpahan relatif, $K L i$ adalah kelimpahan jenis ke-i, dan $\sum K L i$ adalah jumlah kelimpahan semua jenis (Soegianto, 1994).

8. Frekuensi kehadiran: $F i=\frac{J i}{K}$

$F i$ adalah frekuensi kahadiran, $J i$ adalah jumlah kuadrat ditemukannya jenis ke-i, dan $K$ adalah total kuadrat yang dibuat (Krebs, 1978; Fachrul, 2008).

9. Frekuensi kehadiran relatif: $F R=\frac{F i}{\sum F i} \times 100 \%$ $F R$ adalah frekuensi kehadiran relatif, $F i$ adalah frekuensi kehadiran jenis ke-i, dan $\sum F i$ adalah jumlah frekuensi kahadiran semua jenis (Krebs, 1978; Fachrul, 2008).

10. Indeks nilai penting: $I N P=K R+K L R+F R$

$I N P$ adalah indeks nilai penting, $K R$ adalah keraparan relatif, $K L R$ adalah kelimpahan relatif, dan $F R$ adalah frekuensi kehadiran relatif (Soegianto, 1994).

\section{HASIL}

\section{Jenis-jenis mangrove yang ditemukan di perairan pantai Desa Sehati.}

Berdasarkan hasil penelitian yang dilakukan pada setiap petak pengamatan, diperoleh jenisjenis mangrove yang dapat dilihat pada Tabel 1 . 
Tabel 1. Jenis-jenis mangrove yang ditemukan di perairan pantai Desa Sehati

\begin{tabular}{|c|c|c|}
\hline No & Famili & Jenis \\
\hline 1 & Myrsinaceae & $\begin{array}{l}\text { Aegiceras floridum Roem. \& } \\
\text { Schult. }\end{array}$ \\
\hline 2 & Rhizophoraceae & $\begin{array}{l}\text { Bruguiera gymnorhiza (L.) } \\
\text { Lam. }\end{array}$ \\
\hline 3 & Rhizophoraceae & Rhizophora apiculata Blume \\
\hline 4 & Rhizophoraceae & Rhizophora mucronata Poir. \\
\hline 5 & Sonneraticeae & Sonneratia alba $\mathrm{Sm}$. \\
\hline
\end{tabular}

Mangrove yang ditemukan di perairan pantai Desa Sehati sebanyak 5 jenis. Family Rhizoporaceae memiliki jumlah jenis yang banyak ditemukan di lokasi penelitian dibandingkan dengan family yang lain, hal ini ditunjukan pada Tabel 1 dengan jumlah sebanyak 3 jenis yaitu B. gymnorhyza, $R$. apiculata, dan $R$. mucronata.

\section{Nilai indeks keanekaragaman, indeks dominansi, dan indeks kemerataan jenis mangrove di perairan pantai Desa Sehati}

Berdasarkan hasil perhitungan, nilai indeks keanekaragaman, indeks dominansi, dan indeks kemerataan jenis mangrove di pantai Desa Sehati dapat dilihat pada Tabel 2.

Tabel 2. Nilai indeks keanekaragaman (H'), indeks dominansi (C), dan indek kemerataan (E) jenis mangrove di perairan pantai Desa Sehati

\begin{tabular}{cccc}
\hline Parameter & $\begin{array}{c}\text { Indeks } \\
\text { (H') }\end{array}$ & $\begin{array}{c}\text { Indeks } \\
(\mathbf{D})\end{array}$ & $\begin{array}{c}\text { Indeks } \\
(\mathbf{E})\end{array}$ \\
\hline Nilai & 0,965 & 0,893 & 0,348 \\
\hline
\end{tabular}

Keanekaragaman dan kemerataan jenis mangrove di perairan pantai Desa Sehati tergolong rendah, hal ini ditunjukan pada Tabel 2 dengan nilai indeks keanekaragaman $<1$ dan nilai indeks kemerataan <0,4. Sementara itu, dominansi jenis mangrove tergolong tinggi karena nilai indeks dominansi $>0,5$.

\section{Nilai kerapatan, kelimpahan, frekuensi kehadiran, dan indeks nilai penting jenis mangrove di perairan pantai Desa Sehati.}

Berdasarkan hasil perhitungan, nilai kerapatan, kelimpahan, dan frekuensi kehairan jenis mangrove di perairan pantai Desa Sehati dapat dilihat pada Gambar 2.

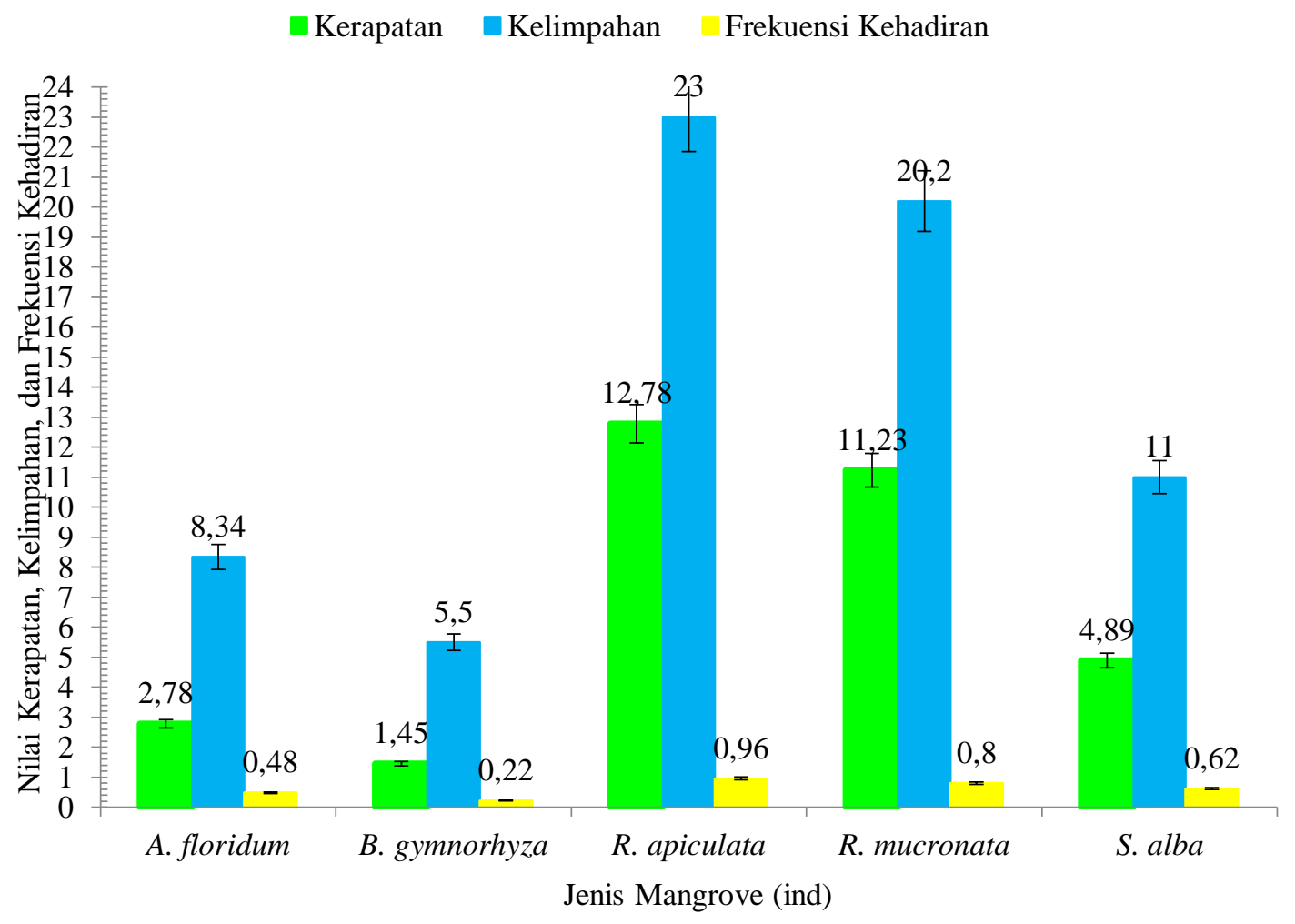

Gambar 2. Histogram nilai kerapatan, kelimpahan, dan frekuensi kehadiran jenis mangrove di perairan pantai Desa Sehati 
Mangrove jenis $R$. apiculata memiliki kerapatan, kelimpahan, dan frekuensi kehadiran yang tertinggi di perairan pantai desa Sehati, hal ini ditunjukan pada Gambar 1 dengan nilai kerapatan $12,78 \mathrm{ind} / \mathrm{m}^{2}$, nilai kelimpahan 23 ind $/ \mathrm{m}^{2}$, dan nilai frekuensi kehadiran $0,96 \%$. Sementara itu, jenis B.gymnorhyza memiliki kerapatan, kelimpahan, dan frekuensi kehadiran yang terendah di lokasi penelitian dengan nilai kerapatan $1,45 \mathrm{ind} / \mathrm{m}^{2}$, nilai kelimpahan, 5,5 ind $/ \mathrm{m}^{2}$, dan nilai frekuensi kehadiran $0,22 \%$. Nilai penting jenis mangrove di perairan pantai Desa Sehati dapat dilihat pada Tabel 3

Tabel 3. Nilai penting jenis mangrove di perairan pantai Desa Sehati

\begin{tabular}{llc}
\hline No & Jenis Mangrove & $\begin{array}{c}\text { Indeks Nilai Penting } \\
(\text { INP })\end{array}$ \\
\hline 1 & A. floridum & 36,24 \\
2 & B. gymnorhyza & 19,62 \\
3 & R. apiculata & 103,56 \\
4 & R. mucronata & 89,56 \\
5 & S. alba & 51,07 \\
\hline
\end{tabular}

Nilai penting mangrove di perairan pantai Desa Sehati yang tertinggi adalah jenis $R$. apiculata, hal ini ditunjukan pada Tabel 3 dengan nilai 103,56. Sementara itu, jenis B. gymnorhyza memiliki nilai penting yang terendah di lokasi penelitian dengan nilai 36,24 .

\section{Kondisi faktor fisika kimia perairan di pantai Desa Sehati}

Berdasarkan hasil pengukuran yang dilakukan pada setiap petak pengamatan, diperoleh rata-rata nilai faktor fisika kimia perairan di pantai desa Haya yang dapat dilihat pada Tabel 4.

Tabel 4. Rata-rata nilai faktor fisika kimia perairan di pantai Desa Sehati

\begin{tabular}{ccccc}
\hline $\begin{array}{c}\text { Suhu } \\
\left({ }^{\circ} \mathbf{C}\right)\end{array}$ & $\begin{array}{c}\text { Kuat arus } \\
(\mathbf{c m} / \text { detik })\end{array}$ & $\begin{array}{c}\text { Kedalaman } \\
(\mathbf{c m})\end{array}$ & $\begin{array}{c}\text { Salnitas } \\
(\mathbf{p p t})\end{array}$ & $\mathbf{p H}$ \\
\hline 25,7 & 24,9 & 135 & 28,9 & 8,1 \\
\hline
\end{tabular}

Kondisi faktor fisika kimia perairan di pantai Desa Sehati masih berada dalam kondisi yang baik bagi pertumbuhan mangrove, hal ini ditunjukan pada Tabel 4 dengan rata-rata suhu air laut $25,7{ }^{\circ} \mathrm{C}$, rata-rata kuat arus $24,9 \mathrm{~cm} /$ detik, rata-rata kedalaman $135 \mathrm{~cm}$, rata-rata salinitas $28,9 \mathrm{ppt}$, dan rata-rata $\mathrm{pH} 8,1$.

\section{PEMBAHASAN}

\section{Jenis-jenis mangrove yang ditemukan di perairan pantai Desa Sehati.}

Mangrove yang ditemukan di perairan pantai Desa Sehati sebanyak 5 jenis. 3 jenis ( $B$. gymnorhyza, $R$. apiculata, $R$. mucronata) berasal dari famili Rhizoporaceae, 1 jenis (A. floridum) berasal dari famili Myrsinaceae, dan 1 jenis $(S$. alba) berasal dari famili Sonneratiacea.

Banyaknya jenis mangrove dari family Rhizoparaceae dikarenakan banyak yang hidup pada substrat berlumpur di lokasi penelitian. Hal ini didukung oleh Noor et al., (2012) yang menyatakan bahwa, jenis mangrove dari famili Rhizoporaceae banyak hidup dan mendominasi pada substrat berlumpur di perairan. Dijelaskan lebih lanjut bahwa famili Rhizoporaceae mendominasi sebagian besar hutan mangrove yang ada di Indonesia. Ditambahkan juga oleh Ernato et al., (2010) bahwa, famili Rhizoporaceae akan tumbuh dan berkembang dengan baik pada substrat berlumpur.

\section{Nilai indeks keanekaragaman, indeks dominansi, dan indeks kemerataan jenis mangrove di perairan pantai Desa Sehati}

Odum (1993) menjelaskan bahwa, jika $H^{\prime}>3$, maka keanekaragaman jenis tinggi; jika $1<H^{\prime}<3$, maka keanekaragaman jenis sedang; dan jika $H^{\prime}<1$, maka keanekaragaman jenis rendah. Berdasarkan kriteria tersebut dapat disimpulkan bahwa keanekaragaman jenis mangrove di pantai Desa Sehati tergolong rendah $(0,965)$.

Nilai keanekaragaman jenis mangrove di perairan pantai desa Sehati tergolong rendah dikarenakan jumlah jenis yang ditemukan sedikit. Akbar et al., (2016); Baksir et al., (2018); dan Soegianto (1994); menjelaskan bahwa, suatu 
komunitas akan memiliki keanekaragaman yang tinggi jika disusun oleh banyak jenis, sebaliknya komunitas akan memiliki keanekaragaman yang rendah jika disusun oleh sedikit jenis.

Penelitian yang dilakukan oleh Acik \&Sudarmaji (2017) di Teluk Pangpang Taman Nasional Alas Purwo menemukan 6 jenis mangrove dengan indeks keanekaragaman tergolong rendah. Adapun penelitian yang dilakukan oleh Rochmady (2015) di Desa Bonea dan Kodiri Kabupaten Muna Sulawesi Tenggara, menemukan 11 jenis mangrove dengan indeks keanekaragaman tergolong sedang. Selain itu juga, penelitian yang dilakukan oleh Darmadi et al., (2012) di Muara Harmin Desa Cangkring Kecamatan Cantigi Kabupaten Indramayu, menemukan 20 jenis mangrove dengan indeks keanekaragaman jenis tergolong tinggi.

Selain jumlah jenis, faktor lain yang menyebabkan rendahnya nilai keanekaragaman jenis mangrove di perairan pantai desa Sehati Kabupaten Maluku Tengah adalah adanya penebangan pohon mangrove yang dilakukan oleh masyarakat untuk dijadikan sebagai kayu bakar dan bahan bangunan. Penebangan tersebut mengakibatkan jumlah jenismangrove berkurang sehingga mempengaruhi keanekaragaman.Adanya aktivitas masyarakat (bersifat antropogenik) di daerah pesisir dapat menyebabkan perubahan pada keanekaragaman jenis mangrove (Alongi, 2002; Hogarth, 2007; Setyawan dkk., 2002; dan Thampanya et al., 2006).

Renta et al., (2016) menjelaskan bahwa, jika $0,5<D<1$, maka dominansi tinggi (terdapat jenis yang mendominansi); dan jika jika $0<D<0,5$, maka dominansi rendah (tidak ada jenis yang mendominansi). Berdasarkan kriteria tersebut dapat disimpulkan bahwa dominansi jenis mangrove di perairan pantai desa Sehati tergolong tinggi $(0,893)$.

Nilai dominansi jenis mangrove di perairan pantai desa Sehati Kabupaten Maluku Tengah tergolong tinggi dikarenakan terdapat jenis yang dominan. Jenis tersebut adalah $R$. apiculata dan
R. mucronata. Kedua jenis mangrove tersebut memiliki adaptasi yang baik serta menguasai dalam lingkungannya. Hal ini sesuai dengan pendapat Alimudin (2010) yang menjelaskan bahwa, jenis yang dominan adalah jenis yang mampu beradaptasi dengan baik serta menguasai terhadap ruang, unsur hara, air, dan cahaya pada lingkungannya daripada jenis yang lain.

Penelitian yang dilakukan oleh Seran (2019) di Pantai Paradiso Kota Kupang Nusa Tenggara Timur, menemukan 2 jenis mangrove dimana jenis A. marina yang mendominasi. Begitupun juga dengan penelitian yang dilakukan oleh Akbar dkk., (2016) di Pulau Mare Kota Tidore Kepulauan Maluku Utara, menemukan 5 jenis mangrove dimana jenis $R$. apiculata yang mendominasi.

Renta et al., (2016) menjelaskan bahwa, jika $E$ $\geq 0,6$, maka kemerataan jenis tinggi; jika $0,4<E$ $<0,6$, maka kemerataan jenis sedang; dan jika $E$ $<$ 0,4, maka kemerataan jenis rendah. Berdasarkan kriteria tersebut dapat disimpulkan bahwa kemerataan jenis mangrove di perairan pantai Desa Sehati tergolong rendah $(0,348)$.

Kemerataan jenis mangrove di perairan pantai Desa Sehati tergolong rendah dikarenakan adanya jenis yang dominan. Jenis yang dominan tersebut menyebabkan kemerataan rendah. Suwardi et al., (2013) menjelaskan bahwa kemerataan berbanding terbalik dengan dominansi. Jika kemerataan jenis dalam komunitas rendah (jumlah jenis tidak sama), maka dominansinya tinggi (ada jenis yang dominan). Sebaliknya, jika kemerataan jenis dalam komunitas tinggi maka dominansinya rendah (tidak ada jenis yang dominan).

Penelitian yang dilakukan oleh Seran (2019) di Pantai Paradiso Kota Kupang Nusa Tenggara Timur, menunjukan bahwa dominansi jenis mangrove tinggi (jenis A. marina dominan) sehingga menyebabkan kemerataan rendah. Begitupun juga dengan penelitian yang dilakukan oleh Akbar dkk.,(2016) di Pulau Mare Kota Tidore Kepulauan Maluku Utara, menunjukan bahwa dominansi jenis mangrove tinggi (jenis $R$. 
apiculata dominan) sehingga menyebabkan kemerataan rendah.

\section{Nilai kerapatan, kelimpahan, frekuensi kehadiran, dan indeks nilai penting jenis mangrove di perairan pantai Desa Sehati.}

Tingginya nilai kerapatan $R$. apiculata dikarenakan memiliki jumlah individu yang terdapat dalam petak pengamatan lebih banyak dibandingkan dengan jenis yang lain. Adapun rendahnya nilai kerapatan Bruguiera gymnorhyza dikarenakan memiliki jumlah individu yang terdapat dalam petak pengamatan sedikit. Soegianto (1994) mejelaskan bahwa, kerapatan ditentukan oleh banyaknya jumlah individu. Semakin banyak jumlah individu, maka semakin tinggi nilai kerapatan dan kelimpahannya. Sebaliknya, semakin sedikit jumlah individu, maka semakin rendah nilai kerapatan dan kelimpahannya.

Selain itu juga, penyebab tingginya nilai kerapatan $R$. apiculata dikarenakan jenis ini mampu beradaptasi dan hidup pada substrat berlumpur. Selain itu juga, memiliki diameter batang yang relatif kecil sehingga tingkat eksploitasi sangat rendah. Nooret al., (2006) menjelaskan bahwa, substrat berlumpur di daerah pantai banyak ditumbuhi oleh mangrove dari family Rhizophoraceae. Adapun rendahnya nilai kerapatan B. gymnorhyza dikarenakan jenis ini banyak dieksploitasi oleh masyarakat karena memiliki diameter batang yang relatif besar.

Tingginya nilai kelimpahan $R$. apiculata dikarenakan memiliki jumlah transek ditemukannya individu tersebut lebih banyak dibandingkan dengan jenis yang lain. Adapun rendahnya nilai kelimpahan $B$. gymnorhyza dikarenakan memiliki jumlah transek ditemukannya individu tersebut sedikit. Soegianto (1994) menjelaskan bahwa, kerapatan dan kelimpahan ditentukan oleh banyaknya jumlah individu. Semakin banyak jumlah individu, maka semakin tinggi nilai kerapatan dan kelimpahannya. Sebaliknya, semakin sedikit jumlah individu, maka semakin rendah nilai kerapatan dan kelimpahannya.
Tingginya nilai frekuensi kehadiran kelimpahan $R$. apiculata dikarenakan jumlah petak pengataman dimana ditemukannya jenis ini lebih banyak dibandingakan dengan yang lain. Adapun rendahnya nilai frekuensi kehadiran $B$. gymnorhyza dikarenakan jumlah petak dimana ditemukannya ajenis ini sangat sedikit. Menurut Akbar et al., (2016), banyaknya jumlah kuadrat dimana ditemukannya jenis sangat mempengaruhi frekuensi kehadiran jenis mangrove.

Tingginya nilai penting $R$. apiculata dikarenakan jenis ini memiliki nilai kerapatan relatif, kelimpahan relatif, dan frekuensi kehadiran relatif yang lebih besar dibandingan dengan jeni yang lain. Adapun rendahnya nilai penting B. gymnorhyza dikarenakan jenis ini memiliki nilai kerapatan relatif, kelimpahan relatif, dan frekuensi kehadiran relatif yang kecil. Nilai penting diperoleh dari hasil penjumlahan beberapa parameter yaitu kerapatan relatif, kelimpahan relatif, dan frekuensi kehadiran relatif (Bengen, 2004).

Selain itu juga, tingginya nilai penting $R$. apiculata dikarenakan jenis ini merupakan vegetasi utama sehingga sangat berperan dan berpengaruh terhadap komunitas mangrove di lokasi penelitian. Hal ini dapat dilihat dari jumlah individu yang lebih banyak dan cenderung mendominasi jenis yang lain. Soegianto (1994) menjelaskan bahwa, indeks nilai penting digunakan untuk membedakan antara jenis yang dominan dengan jenis yang tertekan.

Penelitian yang dilakukan oleh Akbar et al., (2016) di Pulau Mare Kota Tidore Kepulauan Maluku Utara, menemukan bahwa jenis $R$. apiculata memiliki nilai penting yang tertinggi pada stasiun I, stasiun II, dan stasiun III, sedangkan $B$. gymnorhyza memiliki nilai penting yang terendah pada stasiun I, $A$. alba pada stasiun II, dan S. alba pada stasiun III. Begitupun juga dengan penelitian yang dilakukan oleh Sasauw et al., (2016) di Kelurahan Tongkaina Manado menemukan bahwa jenis $R$. apiculata memiliki nilai penting yang tertinggi pada stasiun I, 
sedangkan S. alba memiliki nilai penting yang tertinggi pada stasiun II, dan stasiun III.

\section{Kondisi faktor fisika kimia perairan di pantai Desa Sehati}

a. Suhu

Rata-rata suhu di perairan pantai Desa Sehati sebesar $25,7{ }^{\circ} \mathrm{C}$. Rata-rata suhu tersebut masih berada dalam kondisi yang baik bagi pertumbuhan mangrove. Baksir et al., (2018) menjelaskan bahwa mangrove dapat tumbuh dengan baik pada suhu rata-rata minimal lebih besar dari $20^{\circ} \mathrm{C}$.

\section{b. Kuat arus}

Rata-rata kuat arus di perairan pantai Desa Sehati sebesar $24,9 \mathrm{~cm} /$ detik. Rata-rata kuat arus tersebut masih berada dalam kondisi yang baik bagi pertumbuhan mangrove. Suprihayono (2002) menjelaskan bahwa, kisaran kuat arus yang baik bagi pertumbuhan mangrove adalah 22$30 \mathrm{~cm} /$ detik.

\section{c. Kedalaman}

Rata-rata kedalaman di perairan pantai Desa Sehati sebesar $135 \mathrm{~cm}$.Rata-rata kedalaman tersebut masih berada dalam kisaran yang baik bagi pertumbuhan mangrove. Suprihayono (2002) menjelaskan bahwa kedalaman yang baik bagi pertumbuhan mangrove adalah $1-200 \mathrm{~cm}$.

\section{d. Salinitas}

Rata-rata salinitas di perairan pantai Desa Sehati sebesar 28,9 ppt. Rata-rata salinitas tersebut masih berada kondisi yang baik bagi pertumbuhan mangrove. Suprihayono (2002) menjelaskan bahwa kisaran salinitas yang baik bagi pertumbuhan mangrove adalah 10-30 ppt.

e. $\mathrm{pH}$

Rata-rata salinitas di perairan pantai Desa Sehati sebesar 8,1.Rata-rata $\mathrm{pH}$ masih berada kondisi yang baik bagi pertumbuhan mangrove. Baksir et al., (2018) menjelaskan bahwa, kisaran $\mathrm{pH}$ yang baik bagi pertumbuhan mangrove adalah 6,5-8,5.

\section{SIMPULAN}

Mangrove yang ditemukan di perairan pantai Desa Sehati sebanyak 5 jenis yaitu $A$. floridum, $B$. gymnorhyza, $R$. apiculata, $R$. mucronata dan $S$. alba. Nilai indeks keanekaragaman jenis mangrove tergolong rendah, indeks dominansi jenis mangrove tergolong tinggi, dan indeks kemerataan jenis mangrove tergolong rendah di perairan pantai desa Sehati. $R$. apiculata memiliki nilai kerapatan, kelimpahan, frekuensi kehadiran, dan indeks nilai penting yang lebih tinggi di perairan pantai Desa Sehati. Kondisi faktor fisika kimia (suhu, kuat arus, kedalalaman, salinitas, dan $\mathrm{pH}$ ) diperairan pantai desa Sehati berada dalam keadaan yang baik bagi pertumbuhan mangrove.

\section{UCAPAN TERIMA KASIH}

Penulis mengucapkan terima kasih kepada Direktorat Jenderal Riset dan Pengembangan Kementrian Riset, Teknologi, dan Perguruan Tinggi sebagai penyandang dana untuk penelitian.

\section{KEPUSTAKAAN}

Acick R, Sudarmaji. 2018. Hubungan Faktor Ekologi dengan Struktur Komunitas Tumbuhan Mangrove Teluk Pangpang Taman Nasional Alas Purwo. Jurnal Ilmu Dasar 18(1): 61-64.

Akbar N, Baksir A, Tahir I, Arafat D. 2016. Struktur Komunitas Mangrove di Pulau Mare, Kota Tidore Kepulauan, Maluku Utara, Indonesia. Jurnal Depik 5(3): 133142. ISSN Elektronik: 2502-6194.

Akbar N, Ibrahim A, Haji I, Tahir I, Ismail F, Ahmad M, Kotta R. 2018. Struktur Komunitas Mangrove di Desa Tewe Kecamatan Jailolo Selatan Kabupaten Halmahera Barat Provinsi Maluku Utara. Jurnal Enggano 3(1): 81-97.

Alongi DM. 2002. Present state and future of the world's mangrove forests. Environmental Conservation 29 (3): 331-349.

Alimuddin. 2010. Komposisi dan Struktur Vegetasi Hutan Produksi Terbatas di 
Kabupaten Kolaka Provinsi Sulawesi Tenggara. Jurnal Agriplus 20 (02): 6-11.

Baksir A, Akbar N, Tahir I, Haji I, Ahmad N, Kotta R. 2018. Stuktur Komunitas Hutan Mangrove di Pulau Sibu Kota Tidore Kepulauan Provinsi Maluku Utara. Jurnal Enggano 2(3). E-ISSN 2527-5186.

Ball MC., Pidsley SM. 1995. Growth Responses to Salinity in Relation to Distribution of Two Mangrove Species, Sonneratia alba, Sonneratia lanceolata, in Northern Australia. Funtional Ecology 9(1): 77-85.

Bengen DG. 2004. Mengenal dan Memelihara Mangrove. Pusat Kajian Sumber Daya Pesisir dan Lautan IPB, Bogor.

Darmadi, Lewaru M, Khan AMA. 2012. Struktur Komunitas Mangrove Berdasarkan Karakteristik Substrat di Muara Harmin Desa Cangkring Kecamatan Cantigi Kabupaten Indramayu. Jurnal Perikanan dan Kelautan3(3):347-358. ISSN 2088-3137.

Ernato R, Agustriani F, Aryawati. 2010. Struktur Komunitas Gastropoda pada Ekosistem Mangrove di muara Sungai Batang Ogan Komering Ilir Sumatera Selatan. Jurnal Maspari 01(2): 73-78.

Fachrul MF. 2008. Metode Sampling Bioekologi. Bumi Aksara: Jakarta.

Hogarth PJ. 2007. The Biology of Mangroves and Seagrasses. New York: Oxford University Press Inc.

Indawan E, Ahmadi K, Novitawati RAD. 2012. Komposisi Mangrove pada Lahan Tercemar BTEX dan Logam Berat. Jurnal Perikanan dan Kelautan 14(1): 212-218.

Kariada TM., Andin I. 2014. Peranan Mangrove sebagai Biofilter Pencemaran Air wilayah Tambak Bandeng Tapak, Semarang. Jurnal Manusia dan Lingkungan 21(2): 188-194.

Krebs CJ. 1978. Ecology of Experimental Analisys of Distribution and Abudance. Second edition.Haper anda Row Publisher: New York.

Kustianti. 2011. Manajemen Vegetasi Mangrove. IPB Press: Bogor.

Liline S. 2010. Komunitas Rumput Laut (Seaweed) Di Perairan Pantai Dusun Pulau Osi Desa Eti Kabupaten Seram Bagian Barat sebagai Materi Pembelajaran Muatan Lokal Di Sekolah Menengah Atas. Tesis tidak diterbitkan. Malang: Program Pascasarjana Universitas Negeri Malang.

Noor YS, Khazali M, Suryadiputra INN. 2012. Panduan Pengenalan Mangrove di Indonesia, Wetland International-Indonesia Programme, Bogor: 1-220.

Odum EP. 1993. Dasar-dasar Ekologi. Edisi ke III. Terjemahan Tjahjono Saminga. Gadjah Mada Press: Yogyakarta.

Prasetiyo DE, Zulfikar F, Shinta, Zulkarnain I. 2016. Valuasi Ekonomi Mangrove di Pulau Jawa Kepulauan Seribu :Studi Konservasi Berbasis Green Economy. Omni Akuatika 12(1): 48-54.

Rahmawati. 2006. Upaya Pelestarian Mangrove Berdasarkan Pendekatan Masyarakat. Departemen Kehutanan Fakultas Pertanian Universitas Sumatera Utara. Medan

Renta PP, Pribadi R, Zainuri M, Anggraini M, Utami F. 2016. Struktur Komunitas Mangrove di Desa Mojo Kabupaten Pemalang Jawa Tengah. Jurnal Enggano 1(2).

Rocmahdy. 2015. Struktur dan Komposisi Jenis Mangrove Desa Bonea dan Kodiri Kabupaten Muna Sulawesi Tenggara. Prosiding Simposisum Nasional Kelautan dan Perikanan II Universitas Hasanuddin Makassar.

Sasauw J, Kusen JD, Schaduw JNW. 2016. Struktur Komunitas Mangrove di Kelurahan Tongkaina Manado. Jurnal Pesisir dan Laut Tropis 2(1): 17-22.

Seran W. 2019. Struktur dan Komposisi Spesies Hutan Mangrove di Pantai Paradiso Kota Kupang Nusa Tenggara Timur. Jurnal Agribisnis Perikanan11(1):43-41. EISSN.2598-8298.

Setyawan AD, Winarno K, Purnama PC. 2002. Biodiversitas Genetik, Species, dan Ekosistem Mangrove di Jawa. Kelompok Kerja Biodiversitas Universitas Sebelas Maret. Surakarta: 3-9.

Soegianto A. 1994. Ekologi Kuantitatif. Metode Analisis Populasi dan Komunitas. Usaha Nasional: Surabaya.

Suprihayono. 2002. Pelestarian dan Pengelolaan Sumber Daya Alam di Wilayah Pesisir Tropis. PT. Gramedia Pustaka Utama: Jakarta. 
Thampanya U, Vermaat JE, Sinsakul S, Panapitukkul N. 2006. Coastal erosion and mangrove progradation of Southern Thailand. Estuarine, Coastal and Shelf Science 68: 75-85.

Tuhuteru FD., Mahfuds. 2012. Ekologi, Manfaat, dan Rehabilitasi Hutan Pantai Indonesia. Balai Penelitian Kehutanan Manado. Manado.

Wang L, Meirong Mo, Xiaofei Li, Peng L, Wenqin W. 2010. Differentiation Between True Mangrove and Mangrove Associates Based On Leaf Traits and Salt Contents. Journal of Plant Ecology 1-10. 